\title{
Naturotherapies Based on Minerals
}

\author{
Celso de Sousa Figueiredo Gomes \\ GeoBioTec, Research Center of the Foundation for Science and Technology, University of Aveiro, Aveiro, Portugal \\ Email: cgomes@ua.pt
}

Received September 11, 2012; revised October 9, 2012; accepted October 27, 2012

\begin{abstract}
Since the antiquity, and on an empirical basis, man has accumulated experience on the benefits and risks of minerals (such as, special clay, mud and sand) and other mineral resources (such as, salt, sea water, spring water, underground water, volcanic emissions and dust) on human health. Man and minerals are chemical systems sharing a common composition, comprising major, minor and trace chemical elements, such as, oxygen, hydrogen, carbon, sulphur, phosphor, calcium, magnesium, sodium, potassium, iron, silicon, zinc, selenium, copper, manganese and fluorine, all essential to life, to a high standard of living and to the formation of minerals; in the natural environment where man lives minerals and chemical elements are omnipresent, therefore, interactions are expected to occur and to condition man's life and his standard of living, in turn highly determined by our health state. Examples of the properties and medicinal use of certain types of special clay, certain types of special sand, and certain types of special natural mineral water, thermal or not, in the treatment of particular types of health affections will be disclosed.
\end{abstract}

Keywords: Minerals; Human Health; Naturotherapy; Oligotherapy; Pelotherapy; Psammotherapy; Mineral Water Drinking Cure

\section{Introduction}

Minerals and human body are chemical systems, and in the chemical compositions of both systems the same chemical elements participate, although in different concentrations. The main mineral forming chemical elements are essential constituents of the human body. Also, minerals are conditioners of natural environment and human (or other animal) health. Depending upon their physical and chemical properties, minerals can be essential to keep human health in good shape, but, in certain circumstances, deficiency or excess of minerals can be factors of human disease generation. The recognition that an intimate relationship exists between the natural environment, particularly the geologic materials and processes, and human/animal health, has led to the recent development of a new field of science called Medical Geology [1-4].

The interaction of the natural environment on human health and living quality, particularly when geologic processes and geologic products are involved, currently arouses the interest of scientists, politicians and the communities. According to [3] the aim and scope of Medical Geology would include: 1) Identification and characterization of natural and anthropogenic sources of harmful materials in the environment; 2) Learning to predict the movements and changes in chemical, infectious, and other diseases-causing agents over time and space; 3)
Understanding how people are exposed to such materials and what can be done to minimize or prevent such exposure.

Commenting the adequacy of the expression Medical Geology, on the one hand the term Geology refers to a scientific area whose aim is not limited to chemical elements and minerals, which apparently are the main intervening and conditioning factors on human health. On the other hand the term Medical refers to a scientific area, Medicine, which is not limited to the simple identification and interpretation of the impacts of chemical elements and minerals on human health. In fact, Medicine is based on three independent basic pillars: scientific information, diagnosis and therapeutic. Hence, the aforementioned interaction of geologic processes and products on human heath cannot be limited to the hazardous or negative effects of particular chemical elements on human health, especially certain heavy metals and metalloids of natural or anthropogenic origin, or of particular minerals existent in the environment. Medical Geology should deal with both negative and positive effects of chemical elements and minerals on human health.

Empirical knowledge of human health, whose practice is called Empirical Medicine or Folk Medicine, is essential to many aspects of man's life and activity. However, in regard to this subject, man's quest for rational explanations based on science and technology is hereby considered as equally essential. 
As a matter of fact, with perseverance and step by step, man will be increasingly successful in understanding both positive and negative interaction of minerals and other geo-resources with human health, by using the available accumulated experience and scientific information, both fundamental and applied, provided by specialists in distinctive scientific domains (chemistry, biochemistry, biology, biotechnology, mineralogy, geochemistry, hydro-chemistry, materials science, medicine, public health, pharmacy, nutrition, within others).

The positive or beneficial impacts are reported by various authors, such as: [5-33].

The negative or adverse impacts are reported by various authors, the following deserve particular mention: $[4,30,31,33-45]$.

Several diseases are known to be caused by an exposure to an excessive dose of minerals such as silicosis, asbestosis, selenosis, fluorosis, arsenicosis, manganism, saturnism, hydrargyrism, berylosis, siderosis and baritosis. Most of these diseases are occupational diseases, occupational safety and health being presently an important cross-disciplinary scientific subject. On the other hand, certain health problems are caused by a deficiency of bio-essential elements in food (in [23]).

Minerals are everywhere, in rocks, in soils, in water, and in air (dust), and they could be incorporated in the human body through three distinct pathways: ingestion, inhalation, and dermal absorption, the food ingestion being the main pathway. Depending upon their physical and chemical properties, minerals can be essential to keep human health in good shape but, in certain circumstances, deficiency or excess of minerals can be factors of human disease generation.

The concept of mineral in medical, pharmacological and nutritional sciences is distinct of the concept of mineral in earth sciences, materials sciences and soil sciences. These concepts besides the concepts of mineral salts, of trace minerals or oligoelements, of biominerals, of bioessentiality, of bioavailability, of toxicity, of etiology, and of epidemiology will be dealt with.

Examples of the properties and medicinal use of certain types of special clay, certain types of special sand, and certain types of special natural mineral water, thermal or not, in the treatment of particular types of health affections, are disclosed too.

\section{Naturotherapies Based on Minerals}

At present, there is a growing interest on health treatments involving natural means and procedures, alternative to those of conventional medicine. Hippocrates, born in 458 B.C. (before Christ) in the Greek island of Kos, is considered the Father of Medicine, and of Natural Medicine, in particular. Hippocrates believed that man is part of the Cosmos, and that only Nature could maintain or cure man's illnesses. To achieve this goal, he recommended diet, baths, sun, water and detoxification. He considered health as the perfect state of harmony between natural forces, and believed that the curative vital force should be taken into account by doctors.

Naturotherapy involves different processes and methods, such as: climatotherapy, heliotherapy, thalassotherapy, heliothalassotherapy, aerothalassotherapy, phytotherapy, algotherapy, hydrotherapy, hydrokinesotherapy, hydropressotherapy, balneotherapy, vibrotherapy, halotherapy or salt therapy, thermotherapy, cryotherapy, oligotherapy, mudtherapy, fangotherapy, peloidtherapy or pelotherapy, psammotherapy or arenotherapy, crenotherapy, and hydropenia.

Some of these processes significantly involve the use of minerals and mineral resources, as happens with oligotherapy, pelotherapy, psammotherapy, crenotherapy, and hydropenia.

Examples of benefits related to the medicinal use of certain naturally derived chemical elements (the so-called oligoelements), certain types of clay, certain types of sand, and certain types of natural mineral water used in spa therapy, in the treatment of particular types of health affections are disclosed.

\subsection{Oligotherapy}

In earth sciences, materials sciences and soil sciences, mineral is considered as being a natural, crystalline and inorganic solid, whereas in medical, pharmaceutical and nutrition sciences mineral is considered as being a chemical element of natural and inorganic origin, that is a major or minor constituent of the human body. Depending on their concentrations these chemical elements could be classified into two groups: mineral salts and oligoelements or mineral traces.

There are chemical elements or minerals (25 are actually identified), the so-called bio-essential elements, which are considered essential to humans: some more or less abundant, such as $\mathrm{Ca}, \mathrm{Mg}, \mathrm{Na}, \mathrm{K}$ and $\mathrm{Cl}$ are called mineral salts, and their concentrations are expressed in $\mathrm{mg} \cdot \mathrm{kg}^{-1}$; some others much less abundant, such as, $\mathrm{Cu}$, $\mathrm{Se}, \mathrm{I}, \mathrm{Mn}, \mathrm{Co}$, and $\mathrm{Fe}$ are called trace elements, trace minerals, or oligoelements, and their concentrations are expressed in $\mathrm{ppm} \cdot \mathrm{kg}^{-1}$. Trace elements have a fundamental role in human nutrition and health [46].

The intake or incorporation of the bio-essential minerals by humans takes place essentially through food ingestion (edible vegetables and animal products) and water ingestion. However, it is well known that soil and water differ from place to place (depending on source rock and reservoir rock), both in nature and content of the bio-essential elements (mineral salts and oligoelements). For instance, in what concerns both nature and content, one soil with source on limestome is distinct 
from other soil with source on granite. And we also know that both limestones and granites are not all equal.

Edible vegetables (lettuce, carrot, pumpkin, onion, potato, sweet potato, tomato, cucumber, cauliflower, and broccoli) and fruits (grape, melon, water melon, and passion fruit), grown up on soils developed on the biogenic carbonate sands existing in Porto Santo' island (in the archipelago of Madeira) uptake from the soil bioessential elements such as, $\mathrm{Ca}, \mathrm{Mg}$ and $\mathrm{Sr}$, in a very distinct way of the same edible vegetables and fruits grown up on limestone from another occurrence in other territory of Portugal [23,47]. The vegetables and fruits referred to participate in the daily diet of the users of the local Geomedicine Clinic of Hotel Porto Santo who carrying out programs of psammotherapy (see item 2.3).

The term bioavailability refers to the difference between the amount of a substance, such as a drug, herb, or chemical, to which a person is exposed and the actual dose of the substance the body receives; bioavailability accounts for the difference between exposure and incurporated dose, a drug's therapeutic action or a chemical's toxicity is determined by the dose received at the target site in the body. A certain chemical element can be present in high concentration in the environment and be potentially hazardous; however, if it is present in a bioavailable chemical form, and if other environmental factors $(\mathrm{pH}$, temperature, humidity) do not change the bioavailability, the risk to the heath could be very low.

Depending on their environmental origin and concentration some chemical elements such as $\mathrm{Sb}, \mathrm{As}, \mathrm{Ba}, \mathrm{Pb}$, $\mathrm{Zn}, \mathrm{Cr}$, and $\mathrm{Hg}$ could be toxic or hazardous; their incurporation could take place through food ingestion, air inhalation, and absorption through the skin; the competent studies belong to the scientific domain of ecotoxicology.

The study of the causes responsible for the diseases is called etiology. Also, the systematic medical studies carried out in selected populations bearing certain diseases, in order to find out both positive and negative effects of treatments with natural resources or other resources, is called epidemiology. Table 1 shows, in a synthetic form, what presently is known about the main functions of the most important bio-essential elements.

\subsection{Geophagy and Pelotherapy}

The use of clay and clay minerals by humans for medicinal and wellness purposes is most probably as old as mankind, and within minerals clay due to its ubiquitous occurrence in nature and easy availability was the first to be used, and is still used worldwide.

For medicinal purposes clays or clay bearing materials can be used internally or orally (e.g., the so-called edible clays) or externally (e.g., the so-called peloids).

Some types of clay and edible clay used for therapeutic (healing skin and gastrointestinal ailments), nutria-
Table 1. Main functions of the most important bio-essential chemical elements.

Ca teeth; assists in blood clotting, muscle contraction and nerve transmission; helps reduce risk of osteoporosis; mean content in human body $1200 \mathrm{~g}$ (in a $70 \mathrm{~kg}$ body).

Promotes the activation of over 100 enzymes and helps nerve and muscle functioning; deficiency causes cramps;

Mg intervenes in the maintenance of bone structure and regulates the passage of chemical elements through the cellular membranes; mean content in the human body $25 \mathrm{~g}$.

K Regulates heartbeat, maintains fluid balance and helps muscle contraction; mean content in the human body $125 \mathrm{~g}$.

Keeps the hydro-electrolytic equilibrium and controls muscle

Na contraction and nerve conduction; mean content in the human body $100 \mathrm{~g}$

Fe Essential for red blood cell formation and function; important for brain function.

Cr Aids in glucose metabolism and regulates blood sugar.

Co Promotes the formation of red blood cells; component of vitamin B12.

Promotes the formation of red blood cells and connective

Cu tissue; works as a catalyst to store and release iron to help form haemoglobin; contributes to central nervous system function.

I Needed by the thyroid hormone to support metabolism.

Works with Ca to develop and maintain strong bones and

$\mathbf{P}$ teeth; enhances the use of other nutrients; mean content in human body $780 \mathrm{~g}$.

Needed for muscle protein and hair; its deficiency results in

S degeneration of collagen, cartilage, ligaments, and tendons; mean content in the human body $140 \mathrm{~g}$.

Se Essential component of a key antioxidant enzyme, needed for normal growth and development.

Zn Essential component of more than 200 enzymes involved in digestion, metabolism, reproduction and wound healing.

Mo Contributes to normal growth and development.

F Essential for bones and teeth; Ca by itself cannot build bone; $\mathrm{P}, \mathrm{Mg}, \mathrm{S}$, and $\mathrm{Sr}$ are other essential or important elements.

Si Essential for normal bone growth, and for proper integrity of the skin.

Keeps the hydro-electrolitic equilibrium and controls muscle

Cl contraction and nerve conduction; mean content in human body $100 \mathrm{~g}$.

tional and/or religious purposes have been cited in the literature: [6,15,17,26,48-62].

Geophagy, the deliberate soil-eating, earth-eating, clay eating and pica, have been observed in all parts of the world since antiquity [54,63-68].

Clay ingestion is an ancestral practice still current in several regions of all continents, reflecting cultural practice, religious belief, and physilogical needs, be they nutritional (dietary supplementation) or as a remedy for disease [62].

The main reasons of the ingestion of clay or clayey 
soil are: detoxification of noxious or unpalatable compounds present in diet; alleviation of gasdtrointestinal upsets such as diarrhea; supplementation of the diet with mineral nutrients; and the alleviation of excess acidity in the digestive tract [53].

Clays are mainly used for the treatment of digestive diseases. For instance, clays are widely used against diarrhea to restore hydro-electrolytic balance, due to their capacity of cation exchange. In addition, clays have the capacity to adsorb toxins, which are then evacuated as feces. The minerals used in these cases are smectite and kaolinite $[69,70]$.

Colopathy is a set of functional intestinal signs: abdominal bloating and pains are the most frequent. The effectiveness of beidellite montmorillonite, active princeple of Beidelix on colopathy has been clinically demonstrated [71].

Clays such as smectite and kaolinite have a triple action: they protect the mucous membrane mechanically, as their coating capacity opposes $\mathrm{H}^{+}$ions; they oppose the aggressive factors of injured mucosa by their capacity to adsorb bile salts and certain enzymes such as pepsin; and they stimulate the production of the physiological factors which protect the gastro-duodenal mucosa. Their major disadvantages are constipation and reduction in gastrointestinal absorption of certain drugs taken simultaneously [72-74]. Smecta ${ }^{\mathrm{TM}}$ and Bedelix ${ }^{\mathrm{TM}}$, whose active princeples are diosmectite, and beidellite and montmorillonite respectively, are the most commonly prescribed pharmaceutical formulations.

Clay is also a source of trace elements. The relationship between the presence of trace elements in clay and their possible release in a physiological medium has been investigated by several authors: $[52,54,60,61,63,64,67$, 75-83].

This approach is justified by the fact that: 1) the ingestion of healing clays is becoming more and more common, while the chemical and mineralogical composition of clays on the market is not determined and can sometimes reveal the presence of toxic elements; 2) it is possible to optimize the release of trace elements to supplement the diet of deprived people. Figure 1 shows the preparation, in Haiti, of cakes made with edible clay, salt and grease, for nutritional supplementation of pregnant women. An interesting review of both positive action (dietary supplementation due to the release of trace elements contained in the clay, for instance in the case of iron or zinc deficiency, restoration of the hydro-electrolytic balance caused by diarrhea, detoxification of noxious or unpalatable compounds present in the diet using the adsorption capacity of clay, relief of abdominal pain due excess of stomach acidity, and gastro-esophageal reflux) and negative action (constipation and reduction in

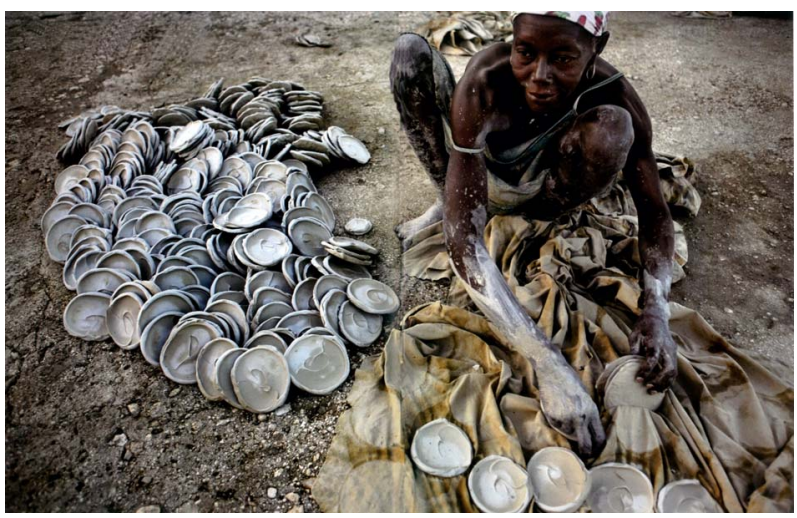

Figure 1. Woman from Haiti, in port-au-prince, preparing a batch of cakes made of clay, salt and grease, particularly used as diet supplement for pregnant women, since food is scarce and expensive (in National Geographic, PT, November, 2008, No. 92, pp. 88-91).

gastrointestinal absorption of certain drugs if ingested simultaneously with clay) of edible clays and of the development of clay-containing formulations for optimization of the oral delivery and gastro-intestinal absorption of some trace elements has been reported [62].

Kaolinite-rich and diosmectite-rich clays are the mostly used clay typologies.

Pelotherapy is a common practice which involves the external or topical use of clay mineral-bearing materials called mud, natural peloid and peloid s.s. (sensu strictu) respectively. The distinctive characteristics of mud, natural peloid and peloid s.s. are shown in Figure 2.

1) Fine particle, wet and sticky natural soil or sediment, that on the basis of its observed characteristics could be considered potentially interesting for either therapeutic or cosmetic applications.

2) Special mud classified as so on the basis of both its relevant specific physicochemical properties assessed in the laboratory and its therapeutic and cosmetic empirical uses; it is a naturally matured mud whose application could be medically and cosmetically validated.

3) Peloid s.s. (sensu strictu) corresponds to a natural peloid or a mixture of clay material with mineral medicinal water that could undergo changes on the composition of both solid and liquid phases when artificial maturation is involved in order to optimize the original properties or to modify them to accomplish certain therapeutic or cosmetic functions medically or cosmetically tested and certified.

4) Medical peloid classified as so on the basis of its therapeutic activity medically tested and epidemiologically appraised.

5) Cosmetic peloid classified as so on the basis of its cosmetic activity duly tested and certified.

The name peloid was created in 1933, and the definition and classification of peloids has undergone changes 
Mud (1) $\rightarrow$ Natural Peloid (2) $\rightarrow$ Peloid s.r. (3) Therapeutic Active Peloid or Medical Peloid (4)

Figure 2. Inter-relationships between mud, natural peloid, and peloid s.s., and the distinctive characteristics and functions of the three materials.

since then. However, the definition and classification most followed are those established by the International Society of Medical Hydrology, during the IV ${ }^{\mathrm{e}}$ Conférence Scientifique Internationale held in Dax, France, in 1949. The defined peloid types were distinguished on the base of three factors: 1) Origin and composition of the solid component; 2) Chemistry and temperature of the natural mineral water; 3) Maturation conditions.

Several papers deal with the study of natural peloids geology, and of natural peloids and peloids (s.s.) properties as well as peloid functions in the human health. Among these papers the following deserve to be enhanced: [10-12,17,18,23,33,58,84-91].

Very recently [91], based on their mineral and chemical composition, peloids have been classified into three groups: 1) Phyllo-peloids characterized by significant participation of phyllosilicates (clay minerals); 2) Organo-peloids characterized by significant participation of organic matter; 3) Sulfo-peloids characterized by significant participation of sulfur, under the forms of native $\mathrm{S}, \mathrm{SH}_{2}$ gas, or metal sulfides.

The so-called extemporaneous peloid currently used in spas, is prepared at the local and time of use, mixing especial clay (bentonite or green clay) with mineral medicinal water or sea water. Also, the so-called parapeloid (really it is not a peloid, otherwise it is a peloid succedaneous) is the result of the blend, for instance, of bentonitic clay and paraffin. It is also called parafango or paramud.

Fangotherapy is a particular type of pelotherapy that involves the use of fango (name of Italian origin attributed to natural peloids deposited from thermal springs, as happens in the case of the volcanic Euganean region, where important thermal resorts occur such as Montecatini, Abano and Battaglia.

There is a close relationship between the natural resources clay and water, the last being essential through the interaction with the rock-forming minerals, for the formation of the first.

On the other hand, water acts as the vehicle that transports in suspension the fine clay particles and provides their deposit. Also, there is an ionic interchange between clay and water, in a degree dependent upon clay global electric charge and ion exchange capacity, and water chemical composition. The main properties of clay minerals that justify their existence and incorporation in natural peloid and peloid s.s. used in spa therapy or health resort medicine and in skin care spa are as follows: fine particle size, platy particle shape, high specific surface area, particle electric charge globally negative, cation and anion exchange capacities, adsorption and absorption capacities, easy dispersion in water, and plasticity.

Unlike the peloid s.s. the natural peloid is naturally maturated. Peloid s.s. is a manipulated or engineered product of a natural peloid, a particular type of mud naturally matured that undergoes a more or less complex process involving both an artificial maturation and the incorporation of certain additives, inorganic or organic, natural or synthetic, in order to potentiate its relevant specific natural properties required to accomplish specific therapeutic or cosmetic functions.

Maturation is really a critical stage in the preparation (refining/beneficiation) of peloids, since it can changes the physical, chemical, and biological characteristics $(\mathrm{pH}$, Eh, grain size and grain size distribution, mineralogy, chemistry and the micro-flora and micro-fauna) of the natural peloid-natural mineral water system.

Several types of peloids are reckoned, based on especial types of mud or natural peloid, such as: thermal spring mud, sea mud, salt lake mud, volcanic mud, peat mud, and bioglea or biofilm mud.

Unlike mud, natural peloid and particularly peloid s.s. are used under medical counseling and supervision, and therefore they could be considered medicines or remedies, although, as a rule, of temporary action as happens with many conventional medicines.

Peloids are being used, for instance, in the treatment of rheumatoid arthritis, osteoarthritis, gynecological disorders, sciatica, skin diseases (acne, seborrhoea, and psoriasis) and in skin care (facial masks with moisturizing, cleansing, exfoliating, reaffirming, anti-wrinkles or anticellulite actions).

In the case of rheumatic diseases a very recent paper [92] discuss the mechanisms of action, so far not fully understood, of spa therapies involving both thermal mineral water and peloids, on such diseases. The authors consider that the net benefit of the treatments could well be the result of a combination of factors, with mechanical, thermal and chemical effects among the most prominent ones.

Peloids are used to accomplish the following purposes:

1) Thermal-chemical treatment-particularly based on peloids analgesic and anti-inflammatory actions; 2) Cosmetic treatment-particularly based on peloids concentration in oligoelements and biologic substances and on their hydrating and absorbing capacities too.

Naturally, both in medical and cosmetic peloids, dermal absorption it is the pathway for the incorporation of those bioactive elements and compounds into the human body. 


\subsection{Psammotherapy}

Some special sands are being used worldwide in a therapeutic application called psammotherapy, particularly for the treatment of muscular-skeletal diseases, under the form of sand-bath.

According to [93] when marine sand is used as a therapeutic agent it provides tonicity to both muscular and locomotor systems. The author says that a sand-bath or psammotherapy is a $10-20$ minutes application of a layer of sand, extracted from the beach down to depths not higher than $30 \mathrm{~cm}$. Also, the author attributes its therapeutic action to the thermal capacity of the sand.

The efficacy of psammotherapy with the production of endogenous corticoids, the increase of glucose content, the decrease of eosinophils, and the increase of the secretion of urinary testoroids have been demonstrated [94].

As a rule, sand is composed of fine grains interspersed with air. Being a porous system, it is characterized by low heat conductivity. Therefore, the sand system is able to release the heat absorbed from the sun's rays without causing burns, in spite of its high thermal gradient.

Although essentially on an empirical basis, psammotherapy has been used for the treatment of the following diseases: osteoarthritis, post-trauma conditions (fractures, sprains, etc.), extra-articular rheumatism, inflamematory rheumatism, and fibromyalgia.

Psammotherapy is a worldwide practice, well represented by the three following examples: 1) Sand-baths in the biogenic carbonate sand occurring on the beaches of Porto Santo island, archipelago of Madeira; 2) Sandbaths in the radioactive sand occurring on the beaches of Guarapari, state of Espírito Santo, Brazil; 3) Sand-baths in the dark volcanic sand occurring in the Thermal Centers of Beppu and Ibusuki, Kyushu island, Japan, which are naturally warmed by geothermal heat.

An interesting example of psammotherapy is practiced in Porto Santo, a relatively small Atlantic island that belongs to the Madeira archipelago. Biogenic carbonate sands formed in the period 30,000 - 15,000 years BP (radiocarbon dating), and outcropping on beaches and dunes, have been locally and empirically used in the treatment of muscular-skeletal affections, such as rheumatoid arthritis, osteoporosis, and fibromyalgia, firstly outdoors since decades ago under the form of sand-bathing, in the dry sand naturally heated by solar radiation of the transition zone from the beach to its adjacent frontal dune, and lately indoors in specialized Geomedicine Clinics and other Health Resorts under medical counseling and supervision.

Porto Santo is an island of volcanic origin with a total area estimated at $42.2 \mathrm{~km}^{2}$ (10 km long by $4 \mathrm{~km}$ wide, approximately), which is part of the archipelago of Madeira, located to the west of southern Europe, between the coasts of Portugal and Morocco, and between the archipelagos of the Azores and the Canary islands.

The source of the biogenic carbonate sand that occurs on the beaches and dunes of the island was a reef that developed during the late Pleistocene, on the shallow north-western coastal shelf of the island. The reef was mostly constituted by calcareous algae, symbiotically associated to corals and other organisms. The fragmentation of the calcareous exoskeletons from the organisms making the bioherm took place due to the abrasion produced by strong sea-waves, as seawater level continuously lowered during the Last Great Glaciation (LGG) and the reef became gradually exposed.

The biogenic carbonate sands from Porto Santo are essentially constituted of platy bioclasts of calcareous algae. X-ray diffraction patterns (Figure 3) show that the biogenic carbonate sand is composed of calcite, Mg-calcite and aragonite.

In summer sunny days sand temperature can reach the scalding temperature of $65^{\circ} \mathrm{C}$. The affected parts of the body are covered with a sand layer about $5 \mathrm{~cm}$ thick, and baths last 20 - 25 minutes. Body acidic sweat partially dissolves the carbonate bioclasts, and the liquid formed at the interface body surface/sand, naturally becomes enriched in $\mathrm{Ca}, \mathrm{Mg}, \mathrm{Sr}$ and other elements, such as $\mathrm{S}, \mathrm{P}$ and I contained in the sand. Both mechanisms, thermal and chemical, of elements incorporation, and the medicinal effects are presented and discussed. The following properties were determined in representative samples of the biogenic carbonate sand from beach deposits and/ or frontal dunes occurring in Porto Santo island: grain size and shape; bioclasts and volcaniclasts' nature and ratio; hardness; specific heat and heat diffusiveness; mineralogical and chemical composition (major, minor and trace elements); $\mathrm{Mg} / \mathrm{Ca}$ and $\mathrm{Sr} / \mathrm{Ca}$ ratios and chemical dissolution rate.

Figure 4 shows a binocular field of a representative sample of the biogenic carbonate sand from Porto Santo. The black grains correspond to titanomagnetite.

The Mhos hardness of the biogenic carbonate sand from Porto Santo, measured after the extraction of the magnetic grains, is 3 , a value that corresponds to the hardness of calcite and is much lower than the value 7 , which corresponds to the hardness of quartz sand, current in continental European beaches. Also, the biogenic carbonate sand from Porto Santo exhibits a yellowish or golden-like color, which explains why Porto Santo is known as the island of the "golden beach". This sand is also characterized by its very fine grain. Around $95 \%$ of the sand grain size lies within the range $0.250 \mathrm{~mm}$ $0.125 \mathrm{~mm}$. All grains of sand have sizes within the range $0.063 \mathrm{~mm}-0.500 \mathrm{~mm}$.

Another fundamental characteristic of the biogenic carbonate sand of Porto Santo, highly relevant in terms of of traditional therapeutic applications, is the predomi- 
X'Pert Graphics \& Identify Graph: Porto Santo HPS

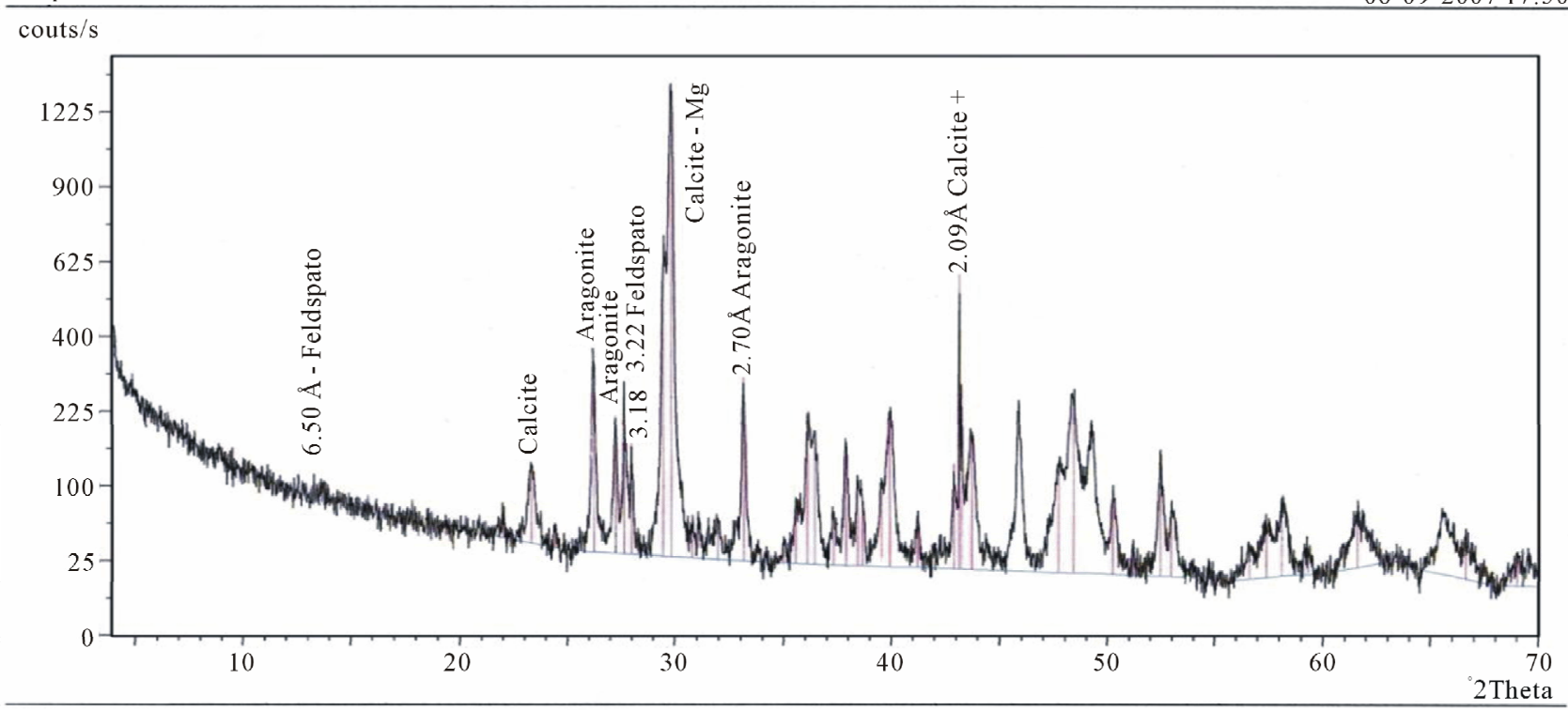

Philips Analytical

Figure 3. X-ray diffraction pattern showing the X-ray diffraction pattern of carbonate minerals present in the biogenic carbonate sand (sample MPSH) of Porto Santo.

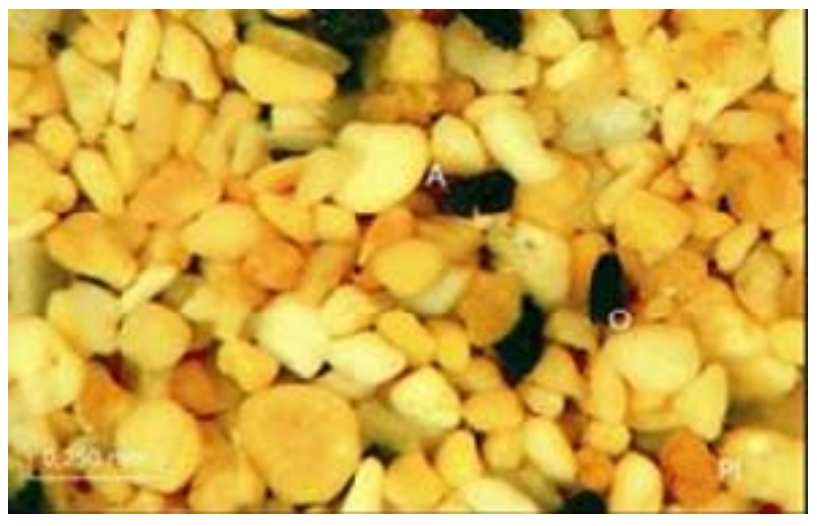

Figure 4. Bioclasts (yellow grains) and Volcaniclasts (black grains) that constitute the biogenic carbonate sand of Porto Santo.

nant tabular shape of its particles (mainly tiny fragments of calcareous algae).

Figure 5 shows the dissolution curves for $\mathrm{Ca}$ and $\mathrm{Mg}$, corresponding to the interaction of the biogenic carbonate sand from Porto Santo with an acid solution $(\mathrm{pH}=$ 5.5) which replicates human sweat.

Whereas $\mathrm{Ca} / \mathrm{Mg}$ ratio in the bulk sample of Porto Santo is about 20 (see Table 2), $\mathrm{Ca} / \mathrm{Mg}$ ratio shown in the dissolution curves is around 4. This means that $\mathrm{Mg}$ related with $\mathrm{Mg}$-calcite enters into solution more rapidly than $\mathrm{Ca}$. Dissolution rates were determined at laboratory temperature $\left(\mathrm{Ca} 20^{\circ} \mathrm{C}\right)$, whereas in sand-baths the dissolution of sand by human sweat takes place at twice the temperature of the laboratory. Also, in sand-baths the

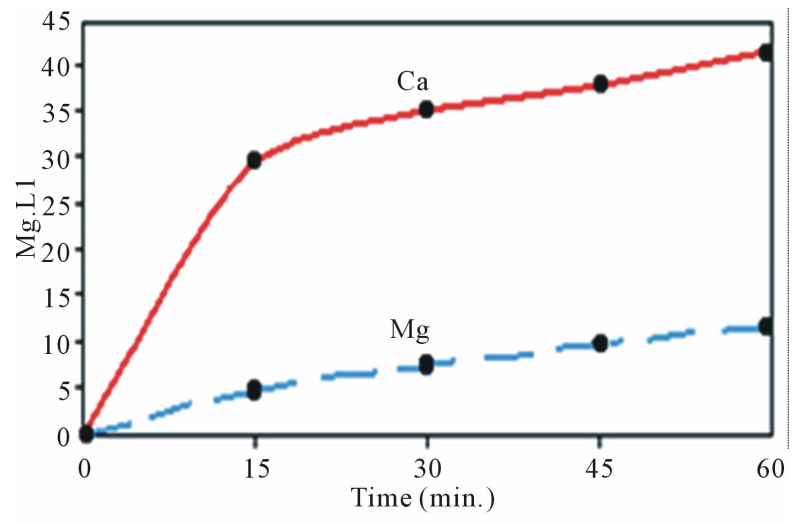

Figure 5. Dissolution rates (expressed in milligrams per liter) of $\mathrm{Ca}$ and $\mathrm{Mg}$ determined on the biogenic carbonate sand of Porto Santo with an acid solution that replicates human sweat.

Table 2. Chemical analysis of major elements (in \%) existing in the biogenic carbonate sand (sample MPSH) from Porto Santo.

\begin{tabular}{cccccc}
\hline & $\mathrm{SiO}_{2}$ & $\mathrm{Al}_{2} \mathbf{O}_{3}$ & $\mathrm{TiO}_{2}$ & $\mathrm{Fe}_{2} \mathbf{O}_{3}$ & $\mathrm{MnO}$ \\
& 1.40 & 1.05 & 0.20 & 0.80 & 0.10 \\
& $\mathbf{C a O}$ & $\mathbf{M g O}$ & $\mathbf{K}_{2} \mathbf{O}$ & $\mathrm{Na}_{2} \mathbf{O}$ & I.L. \\
& 53.10 & 2.50 & 0.31 & 0.50 & 41.40 \\
\hline
\end{tabular}

sweat is being renewed, which explains that the dissolution kinetics would be different from the one verified in the laboratory. 
It is known that the temperature, the crystalline structure and the chemistry, as well as the grain size, shape and porosity of the calcium carbonate species (Mg-calcite, aragonite and calcite) might influence the dissolution kinetics. The studies we have carried out using XRD analysis on the dissolution residues of the biogenic carbonate sand from Porto Santo indicate that as the dissolution progresses, the content of $\mathrm{Mg}$-calcite diminishes.

Figure 4 shows the X-ray diffraction pattern corresponding to the studied sand. Three forms of calcium carbonate were identified in all samples: calcite, $\mathrm{Mg}$ calcite and aragonite, their relative contents varying from sample to sample.

Calcium (Ca), magnesium (Mg), and strontium $(\mathrm{Sr})$ are quantitatively important chemical elements present in the biogenic carbonate sand (see Tables 2 and 3), which are important in terms of health applications. Ca essentially enters the composition of calcite (stable); $\mathrm{Mg}$ essentially enters the composition of Mg-calcite (metastable), and $\mathrm{Sr}$ essentially enters the composition of $\mathrm{Sr}$ aragonite (meta-stable).

Biogenic carbonate sands similar in composition to those occurring in Porto Santo Island, also occur in other islands of the archipelago of the Azores (islands of Santa Maria and Terceira), of the archipelago of the Canary Islands (islands of Gran Canaria, Fuerteventura and Lanzarote) and of the archipelago of Cape Verde (islands of Sal and Boavista). All the archipelagos referred to are part of the bio-geographic archipelago of Macaronesia. However, only in Porto Santo are the biogenic carbonate sands being used for therapeutic purposes, under the form of sand-baths.

In the case of the Porto Santo sand-baths, if the temperature of the sand is above body temperature, the sweat formed dissolves the carbonates of the sand. The chemical elements liberated increase their concentration in the liquid phase, meanwhile formed at the interface sand/ body. After the sand-bath, and before sand removal with a sea-bath or a shower, it is fundamental to dry the body in order to allow the sorption through the skin of the chemical elements existing in the referred to liquid phase.

The carbonate particles that make up the sand, particularly the fragments of calcareous algae which are relatively unstable under acidic conditions, are partially

Table 3. Chemical analysis of minor and trace elements (in ppm) mostly essential to life, making up the biogenic carbonate sand (sample MPSH) from Porto Santo.

\begin{tabular}{lcccccc}
\hline & Sr & P & V & S & Zn & Cu \\
& 590 & 40 & 15 & 20 & 10 & 6 \\
MPSH & Ni & Co & Cr & Se & I & As \\
& 4 & 5 & 9 & 25 & 60 & 5 \\
\hline
\end{tabular}

dissolved by the perspiration liquid that becomes particularly enriched in $\mathrm{Ca}, \mathrm{Mg}, \mathrm{Sr}$, and other chemical elements. As was said before, these elements become free and available to pass through the epidermis and to be absorbed into dermis cells (Figure 6).

To sum up what was said before, the sand from Porto Santo beaches is mainly composed of three calcium carbonates: calcite (calcium carbonate), magnesian-calcite (calcium carbonate showing partial substitution of magnesium for calcium) and aragonite (calcium carbonate showing partial substitution of strontium for calcium).

Experience has shown that the most interesting characteristics of the sand to be used for therapeutic purposes are as follows: 1) highest content of grain size within the range of $0.125-0.250 \mathrm{~mm}$; 2) highest content of tabular shaped grains; 3) lowest content of volcaniclasts and of ferromagnetic minerals; 4) highest content of carbonate minerals; 5) highest content of calcareous algae bioclasts; 6) highest content of Mg-calcite; 7) highest contents of $\mathrm{Sr}, \mathrm{P}, \mathrm{S}, \mathrm{I}$, and F.

It has also been found that parameters (5)-(7) are maximized in the sand whose age, as determined by the radiocarbon method, is the lowest. Currently, in the case of Porto Santo Island, such sand occurs in the beaches and in the dunes that constitute the frontal dune system, occurring, particularly, in the southern coast of the island

As a final note, with the biogenic carbonate sand from Porto Santo some researchers have developed exfoliating formulations to be used in skin care [92].

In a very recent book entitled "Porto Santo Island: Unique Health Resort" [47,95] present much more information on the properties and health effects, not only of the biogenic carbonate sands but also of other natural resources of Porto Santo island.

\subsection{Mineral Water Drinking Cure}

Balneology also called Medical Hydrology is the scientific field that studies the Balneotherapy methods, practices and functions involving medicinal mineral waters (for bathing, drinking and inhalation), products derived from natural mineral water such as peloids, and natural gases for therapeutic purposes inside the facilities of the Health Resort Medicine Centers. It includes disciplines and specialities, such as: medicine, public health, hydrology, hydrogeology, hydrochemistry, physics, microbiology, physiology, physiotherapy, toxicology, epidemiology, health tourism, etc.

Balneotherapy (term used in both English and German speaking countries as well as in central European countries) is equivalent to Crenobalneotherapy (term mainly used in both France and southern European countries).

Mineral water drinking cure is the ingestion of water, particularly medical mineral water, aimed at modification of gastro-intestinal, metabolic, renal and urodynamic 


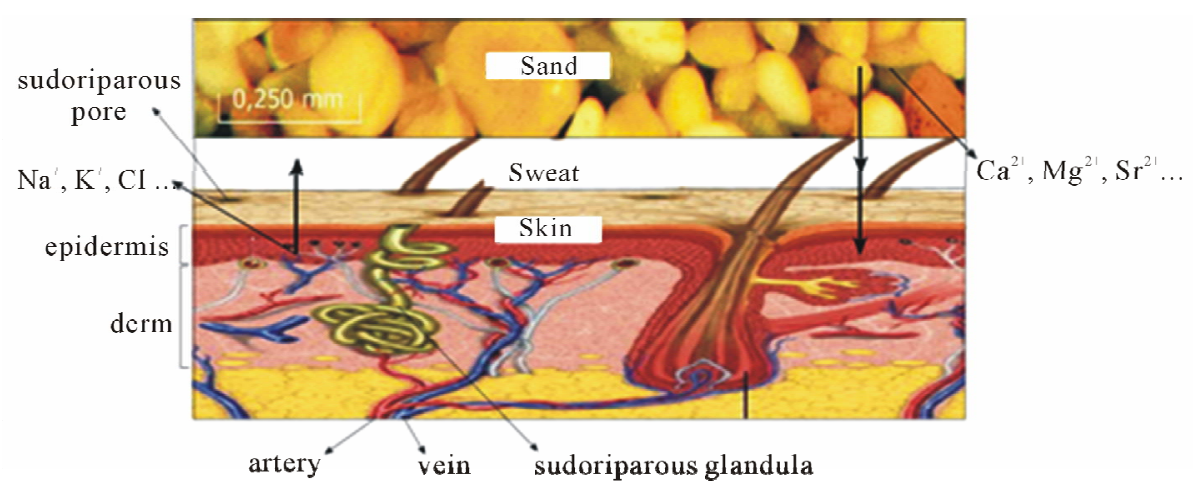

Figure 6. Interaction between the grains of the biogenic carbonate sand from Porto Santo and the human body through an intermediate phase constituted by the sweat of acid character developed on the interface sand/human body during the sand-bath which temperature is slightly higher $\left(40^{\circ} \mathrm{C}-42^{\circ} \mathrm{C}\right)$ than the human body $\left(37^{\circ} \mathrm{C}\right)$; the acidic sweat provides the partial chemical dissolution of the carbonate grains of the sand, and consequently the liberation of $\mathrm{Ca}^{2+}, \mathrm{Mg}^{2+}, \mathrm{Sr}^{2+}$ and the other cations exiting in the grains; finished the sand-bath and without removing the sand film adhered to the sweated body this should be slowly dried in order to allow the absorption through the skin of the elements referred to; finally the sand is removed by shower or sea-bath.

functions.

Specialists in Balneology have gathered much information and have acquired sound experience on the benefits to human health provided by mineral waters, administered orally or applied externally on certain parts of the body, Balnearies.

The WHO (World Health Organization) recognizes the therapeutic interest of medicinal mineral waters, thermal or non-thermal.

Natural mineral water has been considered a millenary curative tool [96]. The Assyrian-Babylonian, Mesopotamian, Egyptian, Persian, Pre-Columbian and Indo-Asian civilizations knew how to take advantage of the healing properties of medicinal mineral waters. Later the Greeks, according to written reports by Herodotus, Hippocrates and Galen, used this type of water, although in an empirical manner.

Approximately 2000 years ago, Thales of Miletus said: "Water constitutes the principle of all things". Later yet, the Romans greatly valued medicinal mineral waters. According to Pliny, the Elder, the Romans developed the practices and methods of hydrotherapy.

Only from the beginning of the $15^{\text {th }}$ century onwards did science provide explanations to the health benefits brought by the ingestion of natural mineral water, in particular after the studies carried out with the water of the Montecatini thermal baths, whose results were published in 1417, in the book entitled "Balneorum Italiae Proprietatibus", written by Ugoline Simone, a famous doctor and founder of Italian Hydrology. Since then, and through periods of more or less interest and demand, the practices of thermalism have been kept up to the present.

The therapeutic effects of natural mineral water depend not only of the chemical properties of water, but also of its thermal and mechanical properties, all of them variable according to the application method.

The application of cold water on particular external parts of the body causes superficial vasoconstriction (expressed by paleness), tachycardia and hyperpnoea. After application, a secondary vasodilatation and the increase of muscular tonus occur. On the other hand, the application of warm water causes superficial vasodilatation (expressed by redness or blushing), low arterial pressure, muscular relaxation and sedation. Taking bath in warm or in cold mineral water has many beneficial health effects, because it conditions blood circulation through the multi-layer human skin. For instance, the primary benefits of heat include: blood vessels dilatation, nervous terminals excitation, breathing acceleration and facilitation and increase of urea production.

Mineral Water Drinking Cure or Mineral Water Drinking Treatment (which consist of the medically-controlled ingestion of certain types of medicinal mineral water, are used for the treatment of hepatic-biliary diseases, metabolic diseases (such as ferropenic anemia) and affections of the digestive system (dyspepsia, gastroesophagic reflux, gastro-duodenal ulcer) [97].

The maximum efficacy of Mineral Water Drinking Cure is attained when water intake takes place near the spring, thus ensuring the preservation of its natural properties: temperature, chemical composition, $\mathrm{pH}$, nature and content of dissolved gases, and radioactivity.

Some medicinal mineral waters have a cathartic action (purgative), others have a diuretic action, and others yet have a diaphoretic action (perspiration increase). The nature and extent of these reactions are dependent upon the predominant chemical constituents and their concentrations [98].

Several diseases have been treated with the administration of medicinal mineral waters, and a list of generic 
diseases includes: 1) diseases of metabolism (obesity, diabetes, gout, rheumatism); 2) diseases of the alimentary or digestive tract (chronic obstipation, chronic diarrhea); 3) diseases of the liver (hyperanemia, cirrhosis); 4) diseases of the urinary tract (kidney stones); 5) diseases of the circulatory system (high blood pressure, cardiac palpitation, anaemia); 6) diseases of the respiratory system (rhinopharyngitis, pharyngitis, laryngitis, emphysema) [98].

Natural mineral water is a general term applied to both spring and other underground continental waters showing specific physical and chemical properties which are stable at their sources; when medically recognized by its healing properties, depending upon mineral nature, content and temperature, natural mineral water is named medical mineral water.

Natural mineral water can be called either thermal or non-thermal. Thermal water is currently defined as a natural mineral water whose temperature, measured at the emergence site, exceeds in $4^{\circ} \mathrm{C}$ the mean air temperature prevailing at the emergence site; the terms hyperthermal $\left(>38^{\circ} \mathrm{C}\right)$, mesothermal $\left(36^{\circ} \mathrm{C}-38^{\circ} \mathrm{C}\right)$ and hypothermal $\left(<36^{\circ} \mathrm{C}\right)$ are used to characterize the temperature of the water, the normal temperature of the human body being the reference.

Nowadays the concept of thermal water is extended to all natural mineral waters which independently of the temperature at their emergence sites occur inside the area of a Thermal Resort and could be used for therapeutic purposes in the Spas of the Thermal Resort [99].

For therapeutic applications natural mineral water temperature is less important than mineral water chemistry, since mineral water temperature is much more easily changed and controlled, particularly inside the Spas. In fact, the concept of natural thermal water has changed along the years; due to the huge water volumes being required inside the Spas of Thermal Resorts.

In general, mineral water is not provided from natural springs but from deep seated water-wells (as a rule, drilled to depths of $250-300 \mathrm{~m}$, or even more). This fact can condition mineral water temperature and chemistry at the emergence site, even if changes are relatively low comparatively to the natural mineral water of the closeby natural thermal spring.

In terms of global mineralization, mineral medicinal water is classified as: hypersaline (total mineralization > $1 \mathrm{~g} / \mathrm{L})$, mesosaline and hyposaline.

Also, in terms of the predominant anions (above 20\% of the total anionic content), mineral medicinal waters with total mineralization $>1 \mathrm{~g} / \mathrm{L}$ are classified in the following main groups: chloride, sulfate, bicarbonate and sulphydrate:

1) Chloride ( $\mathrm{Cl}^{-}$is the major anion) - improves cellular trophism, and tissue cicatrization and renewal, favors both blood and lymph circulation, and stimulates organic and metabolic functions;

2) Sulfate $\left(\mathrm{SO}_{4}^{2-}\right.$ is the major anion)-stimulates bowel peritaltism and has the following effects: purgative or laxative, choleretic (favors the passage of bilis to the bowels through the relaxation of the Oddi sphincter), and cholagogic (increases biliary secretion);

3) Bicarbonate $\left(\mathrm{CO}_{3} \mathrm{H}^{-}\right.$is the major anion) - has an anti-acid effect, increases pancreatic activity, is an heaptoprotector, and favors the mobilization and elimination of uric acid in urine; carbogaseous mineral water (free $\mathrm{CO}_{2}$ superior to $250 \mathrm{mg} / \mathrm{L}$ ) - facilitates digestion;

4) Sulphurous or sulphydrate $\left(\mathrm{SH}^{-}\right.$and $\mathrm{S}^{2-}$ are the major anions, in concentrations well over $0.2 \mathrm{mg} / \mathrm{L}$, to provide the characteristic smell of sulphydric gas) - activates oxi-reduction processes, antioxidant and anti-allergic effects and alleviates pain due to trophism.

Similarly in terms of predominant cations (above 20\% of the total cationic content) medicinal mineral waters with total mineralization $>1 \mathrm{~g} / \mathrm{L}$ are classified as: sodic, calcic and magnesian.

Each natural mineral water has its own structure or chemical and physical specificities, mainly depending on its ionic composition closely related to the mineralogy of the rocks making the aquifer or underground water reservoir.

Some natural mineral waters, with source either in confined aquifers or that circulate along mineralized veins can bear toxic chemical elements in quantities that do not recommend their regular ingestion. It is the case, for instance, of the elements: fluoride, arsenic, selenium, barium and lead.

The dependence of life from water is well expressed in the following phrase due to Jacques Cousteau "The water cycle and the life cycle are one". Approximately $70 \%$ of the weight of the human body consists of water, an indispensable constituent for cellular functioning. All the metabolic processes take place in aqueous medium. Corporal water is divided into three types: intracellular water (occupying the interior of cells); extracellular water (forming plasma, lymph, encephalo-rachidian fluid, and the secretions); and intercellular water (surrounding the cells). A good hydration decreases blood viscosity reducing coronary diseases, decreases the formation of kidney stones, and contributes to the maintenance of a healthy skin.

All the chemical reactions that occur in the human body take place in an aqueous environment, reason why water is indispensable for optimal cellular functioning. In fact, water is the main transportation means for nutrients and other substances in the circulatory system, besides being a vehicle for the elimination of metabolic residues and toxins through the vascular, renal and hepatic systems. Water also plays a fundamental role in the lubrica- 
tion and structural support of tissues and articulations. Water is equally responsible for keeping the body temperature constant, through heat exchanges with the exterior environment.

The fundamental health benefits of water ingestion depend on: 1) Water itself since it allows the maintenance of the degree of body hydration essential to health and life; 2) The mineral and oligoelement contents water may transport, which improve the quality of health; 3) The physicochemical and chemical characteristics of the water, which if ingested in controlled amounts has therapeutic effects and, consequently, is beneficial for health.

In turn, the use of medicinal mineral waters can be considered: 1) Symptomatic therapy of immediate or deferred action; 2) Complementary therapy; 3) Therapy to allow the reduction of medicinal treatments.

The maximum efficacy of water drinking treatment is reached when water intake takes place near the spring, thus ensuring the preservation of its natural properties: temperature, chemical composition, $\mathrm{pH}$, nature and content of dissolved gases, and radioactivity.

\section{REFERENCES}

[1] A. Berger, O. Selinus and C. Skinner, "Medical Geology: An Emerging Discipline,” Episodes, Vol. 24, No. 1, 2001, pp. $43-44$.

[2] C. A. Bowman, P. T. Bobrowsky and O. Selinus, "Medical Geology: New Relevance in the Earth Sciences," Episodes, Journal of International Geoscience, Vol. 26, No. 4, 2003, pp. 270-278.

[3] J. E. Bunnell, "Medical Geology: Emerging Discipline on the Ecosystem-Human Health Interface," EcoHealth, Vol. 1, No. 1, 2004, pp. 15-18. doi:10.1007/s10393-004-0068-8

[4] J. E. Bunnell, R. B. Finkelman, J. A. Centeno and O. Selinus, "Medical Geology: A Globally Emerging Discipline," Geologica Acta, Vol. 5, No. 3, 2007, pp. 273-281.

[5] E. Galán, M. J. Liso and M. Forteza, "Minerales Utilizados en la Industria Farmacéutica," Boletín de la Sociedad Española de Mineralogía, Vol. 8, 1985, pp. 369378.

[6] R. H. S. Robertson, "Cadavers, Choleras and Clays," Bulletin Mineralogical Society, Vol. 113, 1996, pp. 3-7.

[7] G. Novelli, "Applicazioni Medicali e Igieniche Delle Bentoniti," In: F. Veniale, Ed., Atti Convegno, "Argille Curative", Salice Terme (PV), Gruppo Italiano AIPEA, Milano, 1996, pp. 25-33.

[8] G. Novelli, "Applicazioni Cosmetiche e Medicaliu Delle Argille Smectiche," Cosmetic News, Vol. 122, 1998, pp. 350-357.

[9] G. Novelli, "Bentonite: A Clay over the Centuries," Incontri Scientifici, V Corso di Formazione "Metodi di Analisi di Materali Argillosi”, Gruppo Italiano AIPEA, Milano, 2000, pp. 263-304.
[10] F. Veniale, "Argille Curative: Antefatti, Fatti e Misfatti (Healing Clays: Previous Facts, Facts and Wrong Facts)," Proceedings of the Mediterranean Clay Meeting, Mineralogica e Petrographica Acta, Vol. 35A, 1996, pp. 13-44.

[11] F. Veniale, “Applicazioni e Utilizzazioni Medico-Sanitarie di Materiali Argillosi (Naturali e Modificati)," In: N. Morandi and M. Dondi, Eds., Argille e Minerali delle Argille: Guida alla Definizione di Charatteristiche $e$ Proprietá per gli Usi Industriali, Corso di Specializzazione, Gruppo Itaiano AIPEA, Rimini, 1997, pp. 205-239.

[12] F. Veniale, "Le Argille Nelle Terapie Curative: Dalla Leggenda all'Empirismo, Fino al Tempi Moderni, In: Atti Simposio 'Argille per Faghi Peloidi Termai e per Trattamenti Dermatologici e Cosmetici', " Montecatini Terme, Mineralogica et Petrographica Acta, Vol. 42, 1999, pp. 263-265.

[13] A. Lopez-Galindo and C. Iborra, "Usos Farmacéuticos de Arcillas Especiales (Sepiolita y Palygorskita)," In: F. Veniale, Ed., Atti Convegno, "Argille Curative", Salice Terme (PV), Gruppo Italiano AIPEA, Milano, 1996, pp. 4553.

[14] W. R. Reinbacher, "Brief History of Clay in Medicine," Clay Minerals Society News, Vol. 11, No. 1, 1999, pp. 2223.

[15] W. R. Reinbacher, "Healing Earths: The Third Leg of Medicine," 1st Books Library, Bloomington, 2003, pp. 141-144.

[16] A. Lopez-Galindo and C. Viseras, "Pharmaceutical Applications of Fibrous Clays (Sepiolite and Palygorskite) from Some Circum-Mediterranean Deposits," In: C. Gomes, Ed., The 1st Latin American Clay Conference, Funchal, 2000, pp. 258-270.

[17] I. Carretero, "Clay Minerals and Their Beneficial Effects upon Human Health: A Review," Applied Clay Science, Vol. 16, 2002, pp. 155-163.

[18] I. Carretero, C. Gomes and F. Tateo, "Clays and Human Health," In: F. Bergaya, B. Theng and G. Lagaly, Eds., Handbook of Clay Science, Developments in Clay Science, Elsevier Science, Amsterdam, 2006, pp. 717-741.

[19] M. T. Droy-Lefaix and F. Tateo, "Clays and Clay Minerals as Drugs," In: F. Bergaya, B. Theng and G. Lagaly, Eds., Handbook of Clay Science, Developments in Clay Science, Elsevier Science, Amsterdam, 2006, pp. 743-752.

[20] J. B. P. Silva, "Areia de Praia da Ilha do Porto Santo: Geologia, Génese, Dinâmica e Propriedades Justificativas do Seu Interesse Medicinal," Madeira Rochas, Funchal, 2003, p. 344.

[21] C. S. F. Gomes and J. B. P. Silva, "Beach Sand and Bentonite of Porto Santo' Island: Potentialities for Applications in Geomedicine," Madeira Rochas-Divu-lgações Científicas e Culturais, Funchal, 2001, p. 60.

[22] C. S. F. Gomes, "Products Developed from Special Mineral Resources Being Considered Eventually Interesting for Complementary Topical Applications in Balneotherapy," Bulletin du GFA, Vol. 2, 2005, p. 43.

[23] C. S. F. Gomes and J. B. P. Silva, "Minerals and Human Health: Benefits and Risks," Centro de Investigação "Minerais Industriais e Argilas" da Fundação para a 
Ciência e a Tecnologia, Universidade de Aveiro, Aveiro, 2006, p. 300.

[24] C. S. F. Gomes and J. B. P. Silva, "Products Based on Clay and Sand with Interest for Balneotherapy," Clay Science, Vol. 12, No. S2, 2006, pp. 228-232.

[25] C. S. F. Gomes and J. B. P. Silva, "Minerals and Clay Minerals in Medical Geology," Applied Clay Science, Vol. 36, No. 1-3, 2007, pp. 4-21. doi:10.1016/j.clay.2006.08.006

[26] C. S. F. Gomes, R. Hernandez, M. C. Sequeira and J. B. P. Silva, "Characterization of Clays Used for Medicinal Purposes in the Archipelago of Cape Verde," Geochimica Brasiliensis, Vol. 22, No. 3, 2008, pp. 315-331.

[27] C. S. F. Gomes, J. B. P. Silva, M. E. Sequeira and J. H. Gomes, "Potentialities for Therapeutic Purposes of the Biogenic Carbonate Sands Occurring in Some Islands of the Macaronesia' Archipelago Based on Their Unique Chemical and Physical Properties," Geochimica Brasiliensis, Vol. 22, No. 3, 2008, pp. 332-343.

[28] U. Lindh, "Biological Functions of the Elements," In: O. Selinus, B. Alloway, J. A. Centeno, R. B. Finkelman, R. Fuge, U. Lindh and O. Smedley, Eds., Essentials of Medical Geology, Elsevier, Amsterdam, 2005, pp. 115-160.

[29] R. B. Finkelman and U. Limpitlaw, "Health Benefits of Geologic Materials and Geologic Processes," International Journal of Environmental Research and Public Health, Vol. 3, No. 4, 2006, pp. 278-283. doi:10.3390/ijerph2006030042

[30] I. Carretero and M. Pozo, "Mineralogia Aplicada: Salud y Medio Ambiente," Thomson Editors, Madrid, 2007, p. 406.

[31] C. S. F. Gomes, J. B. P. Silva and E. A. F. Silva, "Alvorada e Desenvolvimento da Geologia Médica em Portugal," Encontro Internacional de Termalismo e Turismo Termal \& III Fórum Ibérico de Águas Engarrafadas e Termalismo, Furnas, 2009, pp. 237-252.

[32] C. S. F. Gomes and J. B. P. Silva, "Pelóides: Tipologia, Propriedades, Preparação e Funções," Encontro Internacional de Termalismo e Turismo Termal \& III Fórum Ibérico de Águas Engarrafadas e Termalismo, Furnas, 2009, pp. 219-230.

[33] M. Rautureau, N. Liewig, C. Gomes and M. KatouzianSafadi, "Argiles et Santé: Propriétés et Thérapies," Lavoisier, Paris, 2010, p. 201.

[34] J. O. Nriagu, "Tales Told in Lead," Science, Vol. 281, No. 5383, 1998, pp. 1622-1623. doi:10.1126/science.281.5383.1622

[35] O. Selinus and A. Frank, "Medical Geology," In: L. Moller, Ed., Environmental Medicine, Joint Industrial Safety Council, Stockholm, 2000, p. 327.

[36] M. Edmunds and P. Smedley, "Fluoride in Natural Waters: Occurrence, Controls and Health Aspects," In: O. Selinus, B. Alloway, J. A. Centeno, R. B. Finkelman, R. Fuge, U. Lindh and O. Smedley, Eds., Essentials of Medical Geology, Elsevier, Amsterdam, 2005, pp. 301-329.

[37] R. B. Finkelman, C. W. Skinner, G. S. Lumlee and J. E. Bunnell, "Medical Geology," Geotimes, Vol. 46, No. 11, 2001, pp. 20-23.

[38] J. D. Appleton, "Radon in Air and Water," In: O. Selinus,
B. Alloway, J. A. Centeno, R. B. Finkelman, R. Fuge, U. Lindh and O. Smedley, Eds., Essentials of Medical Geology, Elsevier, Amsterdam, 2005, pp. 227-262.

[39] E. Derbyshire, "Natural Aerosolic Mineral Dusts and Human Health," In: O. Selinus, B. Alloway, J. A. Centeno, R. B. Finkelman, R. Fuge, U. Lindh and O. Smedley, Eds., Essentials of Medical Geology, Elsevier, Amsterdam, 2005, pp. 459-480.

[40] P. Smedley and D. G. Kinniburgh, "Arsenic in Groundwater and the Environment," In: O. Selinus, B. Alloway, J. A. Centeno, R. B. Finkelman, R. Fuge, U. Lindh and O. Smedley, Eds., Essentials of Medical Geology, Elsevier, Amsterdam, 2005, pp. 263-299.

[41] F. Fordyce, "Selenium Deficiency and Toxicity in the Environment," In: O. Selinus, B. Alloway, J. A. Centeno, R. B. Finkelman, R. Fuge, U. Lindh and O. Smedley, Eds., Essentials of Medical Geology, Elsevier, Amsterdam, 2005, pp. 373-415.

[42] R. Fuge, "Soils and Iodine Deficiency," In: O. Selinus, B. Alloway, J. A. Centeno, R. B. Finkelman, R. Fuge, U. Lindh and O. Smedley, Eds., Essentials of Medical Geology, Elsevier, Amsterdam, 2005, pp. 417-433.

[43] Ph. Weinstein and A. Cook, "Volcanic Emissions and Health," In: O. Selinus, B. Alloway, J. A. Centeno, R. B. Finkelman, R. Fuge, U. Lindh and O. Smedley, Eds., Essentials of Medical Geology, Elsevier, Amsterdam, 2005, pp. 203-226.

[44] In: O. Selinus, J. Centeno, R. Finkelman, R. Fuge, U. Lindh and P. Smedley, Eds., Essentials of Medical Geology: Impacts of the Natural Environment on Public Health, Elsevier Academic Press, Amsterdam, 2006, p. 1024.

[45] J. A. Centeno, R. B. Finkelman and O. Selinus, "Medical Geology: Impacts of the Natural Environment on Human Health," XIV Semana de Geoquimica/VIII Congresso de Geoquímica dos Países de Língua Portugueses, Vol. 1, 2005, pp. 15-22.

[46] World Health Organization, "Trace Elements in Human Nutrition and Health," World Health Organization, Genève, 1996, p. 343.

[47] C. S. F. Gomes and J. B. P. Silva, "Ilha do Porto Santo: Estância Singular de Saúde Natural/Porto Santo Island: Unique Natural Health Resort," Madeira Rochas, Funchal, 2012, p. 240.

[48] J. Bech, "Les Terres Medicinals," Discurs per Reial Academia de Farmàcia de Barcelona. Reial Acadèmia de farmàcia de Barcelona-CIRIT (Generalitat de Catalunya), Barcelona, 1987, p. 105.

[49] M. Y. Brouillard and J. G. Rateau, "Pouvoir D'Adsorption de Deux Argiles, la Smectite et le Kaolin sur les Entérotoxines Bactériennes. Etude in vitro sur Culture Cellulaire et sur Intestine de Souriceau Nouveauné," Gastroentérologie Clinique et Biologique, Vol. 13, 1989, pp. 18-24.

[50] J. Bech, “Aspectos Históricos y Técnicos de las Arcillas de uso Medicinal," IX Simp. Grupo Especializado de Cristalografia. La Cristalografia y la Industria Farmacéutica, Ediciones Reales Sociedad Española Fisica y Quimica, Granada, 1996, pp. 15-17. 
[51] J. L. Ziegler, "Geophagy: A Vestige of Paleonutrition," Tropical Medicine and International Health, Vol. 2, No. 7, 1997, pp. 609-611. doi:10.1046/j.1365-3156.1997.d01-359.x

[52] N. Mascolo, V. Summa and V. Tateo, "Characterization of Toxic Elements in Clays for Human Healing Use," Applied Clay Science, Vol. 15, No. 5-6, 1999, pp. 491500. doi:10.1016/S0169-1317(99)00037-X

[53] W. C. Mahaney, M. W. Milner, H. S. Mulyono, R. G. V. Hancock, S. Aufreiter, M. Reich and M. Wink, "Mineral and Chemical Analyses of Soils Eaten by Humans in Indonesia," International Journal of Environmental Health Research, Vol. 10, No. 2, 2000, pp. 93-109. doi:10.1080/09603120050021100

[54] F. Tateo, V. Summa, C. G. Bonelli and G. Bentivenga, "Mineralogy and Geochemistry of Herbalist's Clays for Internal Use: Simulation of the Digestive Process," Applied Clay Science, Vol. 20, No. 3, 2001, pp. 97-109. doi:10.1016/S0169-1317(01)00079-5

[55] A. Woywodt and A. Kiss, "Geophagia: The History of Earth-Eating," Journal of Royal Society of Medicine, Vol. 95, No. 3, 2002, pp. 143-146. doi:10.1258/jrsm.95.3.143

[56] M. J. Wilson, "Clay Mineralogical and Related Characteristics of Geophagic Materials," Journal of Chemical Ecology, Vol. 29, No. 7, 2003, pp. 1525-1547. doi:10.1023/A:1024262411676

[57] M. Nchito, P. W. Geissler, L. Mubila, H. Friis and A. Olsen, "Effects of Iron and Multimicronutrient Supplementation on Geophagy: A Two-by-Two Factorial Study among Zambian Schoolchildren in Lusaka," Transactions of the Royal Society of Tropical Medicine and Hygiene, Vol. 98, No. 4, 2004, pp. 218-227. doi:10.1016/S0035-9203(03)00045-2

[58] F. Tateo, V. Summa, M. L. Gianossi and G. Ferraro, "Healing Clays: Mineralogical and Geochemical Constraints on the Preparation of Clay-Water Suspension (Argillic Water)," Applied Clay Science, Vol. 33, No. 3-4, 2006, pp. 181-194. doi:10.1016/j.clay.2006.05.004

[59] L. B. Williams, S. E. Haydel, R. F. Giese and D. D. Eberl, "Chemical and Mineralogical Characteristics of French Green Clays Used for Healing," Clays and Clay Minerals, Vol. 56, No. 4, 2008, pp. 437-452.

[60] O. J. R. Kikouama, F. Le Cornec, S. Bouttier, A. Launay, L. Baldé and N. Yagoubi, "Evaluation of Trace Elements Released by Edible Clays in Physicochemically Simulated Physiological Media," International Journal of Food Sciences and Nutrition, Vol. 60, No. 2, 2009, pp. 130-142. doi:10.1080/09637480701614956

[61] O. J. R. Kikouama, K. L. Konan, A. Katty, J. P. Bonnet, L. Baldé and N. Yagoubi, "Physicochemical Characterization of Edible Clays and Release of Trace Elements," Applied Clay Science, Vol. 43, No. 1, 2009, pp. 135-141. doi:10.1016/j.clay.2008.07.031

[62] O. J. R. Kikouama and L. Baldé, "From Edible Clay to Clay-Containing Formulation for Optimization of the Oral Delivery of Some Trace Elements: A Review," International Journal of Food Science and Nutrition, Vol. 61, No. 8, 2010, pp. 1-21.

[63] J. M. Hunter and R. De Kleine, "Geophagy in Central
America," The Geographical Review, Vol. 74, No. 2, 1984 , pp. 157-169. doi:10.2307/214097

[64] T. Johns and M. Duquette, "Detoxification and Mineral Supplementation as Function of Geophagy," American Journal of Clinical Nutrition, Vol. 53, No. 2, 1991, pp. 448-456.

[65] R. Reid, "Cultural and Medical Perspectives on Geophagia," Medical Anthropology, Vol. 13, No. 4, 1992, pp. 337-351. doi:10.1080/01459740.1992.9966056

[66] P. W. Abrahams and J. A. Parsons, "Geophagy in the Tropics: A Literature Review," Geographical Journal, Vol. 162, No. 1, 1996, pp. 63-72. doi:10.2307/3060216

[67] S. Aufreiter, R. G. V. Hancock, W. C. Mahaney, A. Stambolic-Robb and K. Sanmugadas, "Geochemistry and Mineralogy of Soils Eaten by Humans," International Journal of Food Sciences and Nutrition, Vol. 48, No. 5, 1997, pp. 293-305. doi:10.3109/09637489709028575

[68] R. K. Gribsky, B. A. Thyer, R. J. Waller and G. A. Johnston, "Chalk Eating in Middle Georgia: A Culture-Bound Syndrome of Pica?" Southern Medical Journal, Vol. 92, No. 2, 1999, pp. 190-192. doi:10.1097/00007611-199902000-00005

[69] J. Fioramonti, M. T. Droy-Lefaix and I. Bueno, "Effet d'un Composé Argileux sur les Modifications de la Motricité Gastro-Intestinale Induite par la Toxine Cholérique et la Diarrhée Osmotique Expérimentale chez le Chien," Digestion, INRA, Toulouse, 1987, pp. 2430-2437.

[70] O. Kheroua, J. Juteau, D. Tome and J. Y. Desjeux, "Action de la Smectite en Présence de la Toxine Cholérique et de la Solution de Réhydratation sur les Mouvements D'eau et des Electrolytes Dans L'intestin de Rat, in Vivo," IPSEN, Cambronne, Paris, 1989.

[71] M. A. Bigard and C. Gilbert, "Étude en Double Aveugle de L'effet du Bedelix sur la Surproduction de Gaz Intestinaux Induite par un Repas Rich en Flatulents," Médicine et Cirurgie Digestives, Vol. 19, 1990, pp. 317-319.

[72] J. L. White and S. L. Hem, "Pharmaceutical Aspects of Clay-Organic Interactions," Industrial Engineering Chemistry Product Research and Development, Vol. 22, No. 4, 1983, pp. 665-671. doi:10.1021/i300012a028

[73] M. J. Sánchez Martín, M. Sánchez Camazano, M. L. Sayalero and A. Dominguez Gil, "Physicochemical Study of the Interaction of Montmorillonite with Hydralazine Hydrochloride, a Cardiovascular Drug," Applied Clay Science, Vol. 3, No. 1, 1988, pp. 53-61. doi:10.1016/0169-1317(88)90005-1

[74] J. Cornejo, "Las Arcillas en Formulaciones Farmacéuticas," In: E. Galán and M. Ortega, Eds., Conferencias de IX y X Reuniones de la Sociedad Española de Arcillas, SEA, Madrid, 1990, pp. 51-68.

[75] D. E. Vermeer, "Geophagy among the Tiv of Nigeria," Annals of the Association of American Geographers, Vol. 56, No. 2, 1996, pp. 197-204.

[76] D. E. Vermeer, "Geophagy among the Ewe of Ghana," Ethnology, Vol. 10, No. 1, 1971, pp. 56-72. doi: $10.2307 / 3772799$

[77] J. M. Hunter, "Geophagy in Africa and in the United States: A Culture-Nutrition Hypothesis," Geographical 
Review, Vol. 63, No. 2, 1973, pp. 170-195. doi: $10.2307 / 213410$

[78] P. W. Abrahams and J. A. Parsons, "Geophagy in the Tropics: An Appraisal of Three Geophagical Materials," Environmental Geochemistry and Health, Vol. 19, No. 1, 1997, pp. 19-22.

[79] B. Smith, B. G. Rawlings, M. J. A. R. Cordeiro, M. G. Hutchins, J. G. Tiberindwa, L. Sserunjogi and A. M. Tomkins, "The Bioaccessibility of Essential and Potentially Toxic Trace Elements in Tropical Soils from Mukono District, Uganda," Journal of the Geological Society of London, Vol. 157, No. 4, 2000, pp. 885-891. doi:10.1144/jgs.157.4.885

[80] P. S. Hooda, C. J. K. Henry, T. A. Seyoum, L. D. M. Armstrong and M. B. Fowler, "The Potential Impact of Soil Ingestion on Human Mineral Nutrition," Environmental Geochemistry and Health, Vol. 24, No. 4, 2002, pp. 305-319. doi:10.1023/A:1020542810334

[81] P. S. Hooda, C. J. K. Henry, T. A. Seyoum, L. D. M. Armstrong and M. B. Fowler, "The Potential Impact of Soil Ingestion on Human Mineral Nutrition," Science of the Total Environment, Vol. 333, No. 1-3, 2004, pp. 7587. doi:10.1016/j.scitotenv.2004.04.023

[82] N. Mascolo, V. Summa and F. Tateo, "In Vivo Experimental Data on the Mobility of Hazardous Chemical Elements from Clays," Applied Clay Science, Vol. 25, No. 1-2, 2004, pp. 23-28. doi:10.1016/j.clay.2003.07.001

[83] O. J. R. Kikouama, N. Yagoubi, B. Legendre and L. Baldé, "Salting out of Elements $\mathrm{Mg}$ and $\mathrm{Ca}$ by Clay in Physiological Gastro-Intestinal Mediums Physicochemically Simulated," Applied Clay Science, Vol. 35, No. 1-2, 2007, pp. 1-10. doi:10.1016/j.clay.2006.06.009

[84] C. Porlezza, "Considerazione Sui Fanghi Terapeutici (Peloidi)," Thermae, Vol. 2, No. 2-3, 1965, pp. 6-57.

[85] A. Rambaud, "Les Boues Thermales," In: H. Chr, Ed., Crénotherapie et Réadaptation, Masson, Paris, 1989, pp. 919.

[86] F. Armijo, "Propriedades Térmicas de los Peloides," Boletin (Sociedad Espanola de Hidrologia Medica), Vol. 6, No. 3, 1991, pp. 151-158.

[87] J. San Martin Bacaicoa, "Peloides en General: Características Físicas, Efectos Biológicos e Indicaciones Terapéuticas," In: M. Armijo and J. San Martin, Eds., Curas Balneárias y Climáticas, Talasoterapia y Helioterapia, Complutense, Madrid, 1994, pp. 315-331.

[88] F. Veniale, A. Bettero, P. Jobstraibizer and M. Setti, "Thermal Muds: Perspectives of Innovation," Applied
Clay Science, Vol. 36, No. 1-3, 2007, pp. 141-147. doi:10.1016/j.clay.2006.04.013

[89] C. Viseras, C. Aguzzi, P. Cerezo and A. Lopez-Galindo, "Uses of Clay Minerals in Semisolid Health Care and Therapeutic Products," Applied Clay Science, Vol. 36, No. 1-3, 2007, pp. 37-50. doi:10.1016/j.clay.2006.07.006

[90] Sh. Tserenpil, G. Dolman and M. G. Voronkov, "Organic Matters in Healing Muds from Mongolia," Applied Clay Science, Vol. 49, No. 1-2, 2010, pp. 55-63. doi:10.1016/j.clay.2010.04.002

[91] M. Pozo, M. I. Carretero, E. Pozo, J. A. Martin Rubi and F. Maraver, "Caracterización Mineralógica y Química de Peloides Espanõles y Argentinos: Evaluación de Elementos Traza Potencialmente Tóxicos," In: F. Maraver and M. I. Carretero, Eds., Libro de Resúmenes del II Congreso Iberoamericano de Peloides, Lanjarón, C.E.R.S.-A., Madrid, 2010, pp. 37-38.

[92] A. Fioravanti, L. Cantarini, G. M. Guidelli and M. Galeazzi, "Mechanisms of Action of Spa Therapies in Rheumatic Diseases: What Scientific Evidence Is There?" Rheumatology International, Vol. 31, No. 1, 2011, pp. 1-8.

[93] P. C. Federicci, "Sabia, Limi e Alghe Nella Talassoterapia," In: Gualterotti, Ed., Proceedings of the 1st World Thermalism Congress on Progress in Medical Hydrology, Climatology and Thalasotherapy, Lido di Lesolo, Venezia, 1980, pp. 40-44

[94] A. Murgia, "Hipótesis Sul le Mecanismo D'aczione Della Psammoterapia," In: Gualterotti, Ed., Proccedings of the 1st World Thermalism Congresso on Progress in Medical Hydrology, Climatology and Thalasotherapy, Lido di Lesolo, Venezia, 1980, pp. 45-49.

[95] D. Santos, M. H. Amaral, M. Padilha, T. Andreani, M. R. Pena Ferreira, J. Silva and C. Gomes, "Development of Exfoliating Formulations Containing Biogenic Carbonate Sand from Porto Santo Island, Madeira Archipelago," Skin and Formulation, 3rd Symposium, Versailles, 2009.

[96] F. Maraver, "El Agua Mineromedicinal: Una Herramienta Curative Milenaria," Tribunatermal, Vol. 11, 2008, pp. 54-57.

[97] M. Arribas, "Cura Hidropinica," Tribunatermal, Vol. 12 , 2008, pp. 46-48.

[98] L. D. George, "Uses of Spring Water,” In: P. E. LaMoreaux and J. T. Tanner, Eds., Springs and Bottled Waters of the World, Springer-Verlag, Berlin, 2001, p. 315.

[99] F. Teixeira, "Hidrologia Médica," 2nd Edition, Coordenação de Flávio Reis, Instituto de Climatologia e Hidrologia da Universidade de Coimbra, Coimbra, p. 171. 